\title{
EFFECT OF MOLYBDATE ON THE STRESS CORROSION CRACKING OF 2205 DUPLEX STAINLESS STEEL IN SULFURIC ACID SOLUTION
}

\author{
VPLIV MOLIBDATA NA NAPETOSTNO KOROZIJSKO POKANJE \\ DUPLEKS NERJAVNEGA JEKLA 2205 V RAZTOPINI ŽVEPLENE \\ KISLINE
}

\author{
Guo Yi, Shanshan Xing, Haoyu Qi, Junhua Xu, Chuanbo Zheng* \\ School of Materials Science and Engineering, Jiangsu University of Science and Technology, 212003 Zhenjiang, Jiangsu, China \\ Prejem rokopisa - received: 2018-06-20; sprejem za objavo - accepted for publication: 2019-05-29
}

doi:10.17222/mit.2018.124

\begin{abstract}
The inhibition effect of molybdate on stress corrosion cracking (SCC) was investigated by many researchers, but few considered the molybdate effect on hydrogen permeation and the relationship between SCC and hydrogen permeation. This paper presents the effect of molybdate on SCC susceptibility and hydrogen permeation through the 2205 super duplex stainless steel in a sulfuric acid solution. An addition of molybdate has an interesting influence. It decreases the SCC susceptibility. With its increasing concentration, the inhibition effect on the hydrogen permeation remains steady. Attempts were made to understand this behaviour based on the role of molybdate in hydrogen permeation and pitting characteristics of the 2205 stainless steel in a sulfuric acid solution.

Keywords: duplex stainless steel, electrochemical impedance spectroscopy, hydrogen permeation, molybdate, stress corrosion cracking
\end{abstract}

Mnogi raziskovalci so že preučevali zaviralni učinek molibdata na napetostno korozijsko pokanje (SCC), medtem ko je manj raziskovan njegov učinek na prodiranje vodika v povezavi z njim. V članku avtorji predstavljajo vpliv molibdata na dovzetnost superdupleks nerjavnega jekla, vrste 2205, za SCC in prodiranje vodika v raztopini žveplene kisline. Dodatek molibdata ima zanimiv vpliv v smislu zmanjšanja dovzetnosti jekla za SCC. S povečevanjem njegove koncentracije se njegov zaviralni učinek na prodiranje vodika ustali. Avtorji so v raziskavi pozornost namenili razumevanju tega obnašanja na osnovi vloge molibdata pri prodiranju vodika in značilnostih jamičaste korozije jekla 2205 v žvepleni kislini.

Ključne besede: dupleks nerjavno jeklo, elektrokemična impedančna spektroskopija (EIS), prodiranje vodika, molibdat, napetostno korozijsko pokanje (SCC)

\section{INTRODUCTION}

$\mathrm{MoO}_{4}^{2-}$ is a good anionic corrosion inhibitor for carbon steels in neutral and alkaline environments. The role of molybdate as an inhibitor that improves the pitting-corrosion resistance has been studied for several decades. ${ }^{1-5}$ S. A. M. Refaey et al. ${ }^{1,2}$ found that inorganic molybdate prevented pitting corrosion in both sodium chloride and an acidified solution by increasing the pitting potential. The inhibition of the pit nucleation and growth on the passive surface of pure iron was studied by E. Fujioka. ${ }^{6}$ The results showed that $\mathrm{MoO}_{4}{ }^{2-}$ repaired passive-film defects and inhibited the growth of pitting corrosion. C. R. Alentejano et al. ${ }^{4}$ reported that molybdate prevented pitting corrosion in pure water by increasing the pitting potential. ${ }^{4}$ The effects of $\mathrm{MoO}_{4}{ }^{2-}$ on the corrosion inhibition of mild steel was studied by $\mathrm{M}$. Saremi et al. ${ }^{7}$ who reported that the inhibition efficiency of $\mathrm{MoO}_{4}{ }^{2-}$ was increased with an increasing $\mathrm{MoO}_{4}{ }^{2-}$ concentration. Furthermore, the determination of the critical pitting temperature revealed that molybdate has a

*Corresponding author's e-mail:

15952802516@139.com (Chuanbo Zheng) positive effect on the corrosion resistance of 2205 duplex stainless steels. ${ }^{5}$ In summary, there are reports on the effects of molybdates on the pitting and SCC behaviour of steels in chloride solutions. ${ }^{1-12}$ The majority of these reports suggested the use of the inhibiting effects of molybdates on stainless-steel pitting. However, all these studies ignore the effect of molybdates on hydrogen permeation.

2205 duplex stainless steels (DSS) with a dual-phase microstructure consisting of ferrite $(\alpha)$ and austenite $(\gamma)$ show a considerable resistance to pitting and SCC; so they are used in the petroleum and nature-gas industries and in chemical tankers. ${ }^{13-16}$ The SCC mechanism of steel was widely investigated with various methods. The anodic-dissolution theory, ${ }^{17,18}$ hydrogen embrittlement, ${ }^{19,20}$ and synergistic effects of film-induced stress and hydrogen embrittlement ${ }^{21,22}$ were used to explain the development process of SCC. As for DSS, the anodic dissolution rate is slow, some researchers use the film-induced-stress theory to explain the mechanism and get good results. Unfortunately, in these studies, the hydrogen effect is usually ignored. 
Therefore, in our study, the effect of molybdate on the SCC of the 2205 DSS was investigated using a slow-strain-rate test (SSRT) in chloride solutions without and with different levels of the molybdate content. Microscopy was carried out to investigate the pitting corrosion; a hydrogen-permeation test was conducted to investigate the hydrogen-permeation effect on SCC. Moreover, Raman spectroscopy was applied to analyse the surfaces of the specimens.

\section{EXPERIMENTAL PART}

\subsection{Materials}

The specimens represented the 2205 DSS with the following composition (in mass fractions, w/\%): $0.02 \%$ C, $0.97 \% \mathrm{Mn}, 0.022 \% \mathrm{P}, 0.001 \% \mathrm{~S}, 0.74 \% \mathrm{Si}$, $21.61 \% \mathrm{Cr}, 5.31 \% \mathrm{Ni}, 3.07 \% \mathrm{Mo}, 0.18 \% \mathrm{~N}$ and $\mathrm{Fe}$ balance. Aging treatment was applied at $1050{ }^{\circ} \mathrm{C}$ for $30 \mathrm{~min}$, followed by quenching in water. Figure 1 shows the microstructure of the 2205 DSS.

\subsection{Slow-strain-rate test}

A test solution of sulphuric acid $\left(\mathrm{H}_{2} \mathrm{SO}_{4}\right)$ including sodium chloride $(\mathrm{NaCl})$ was used for the SCC stut dies. ${ }^{23,24}$ The SSRT test was carried out to investigate the $\mathrm{SCC}$ susceptibility in $0.2 \mathrm{~mol} / \mathrm{L} \mathrm{H}_{2} \mathrm{SO}_{4}+3.5 \% \mathrm{NaCl}+\mathrm{x}$ $\mathrm{mol} / \mathrm{L} \mathrm{Na}_{2} \mathrm{MoO}_{4}(\mathrm{X}=0,0.005,0.05,0.2)$ and a charging current of $-5 \mathrm{~mA} / \mathrm{cm}^{2}$ was used simultaneously. The SSRT experimental specimens were rods with working sections in the middle. ${ }^{25}$ Each specimen was polished along the tensile direction with 1000-grit emery paper, degreased in acetone and washed with distilled water immediately before the test. The specimens were completely immersed in the test solutions during the whole test at $20^{\circ} \mathrm{C}$ and the strain rate was $10^{-1} \mathrm{~S}^{-1}$. All the tests were performed in triplicate.

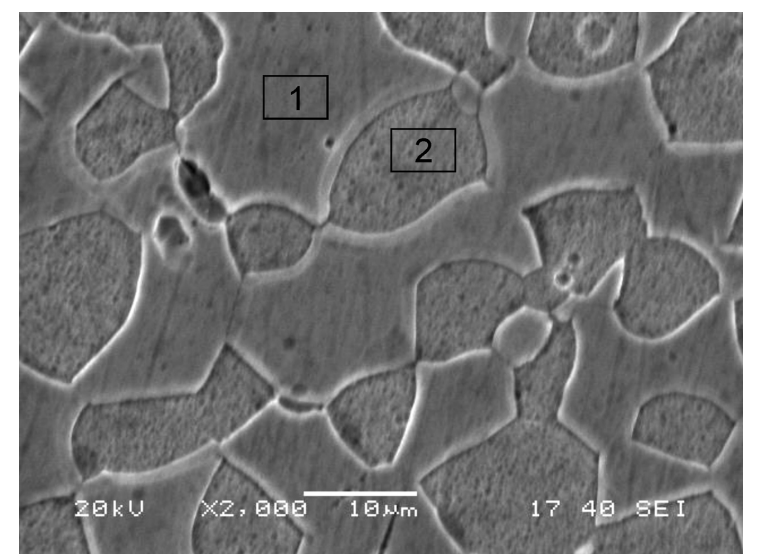

Figure 1: Microstructure of DSS 2205 with: 1) ferrite phase $(\alpha)$ and 2) austenite phase $(\beta)$

\subsection{Hydrogen-permeation test}

Hydrogen-permeation experiments were conducted using D-S double cells at 20 \#. Disc-plate specimens of $40 \mathrm{~mm}$ in diameter and $0.2 \mathrm{~mm}$ in thickness were used as working electrodes. The surfaces of both sides of the steel were polished to $1 \mu \mathrm{m}$, then washed with isopropyl alcohol and rinsed with distilled water, followed by air drying. One side of each specimen was coated with a thin layer of nickel. A solution containing $250 \mathrm{~g} / \mathrm{L}$ $\mathrm{NiSO}_{4} \cdot 6 \mathrm{H}_{2} \mathrm{O}, 45 \mathrm{~g} / \mathrm{L} \mathrm{NiCl} 2 \cdot 6 \mathrm{H}_{2} \mathrm{O}$ and $40 \mathrm{~g} / \mathrm{L} \mathrm{H}_{3} \mathrm{BO}_{3}$ was used as the coating solution. The coating current density was $-3 \mathrm{~mA} / \mathrm{cm}^{2}$ and the coating time was $3 \mathrm{~min}$. It was previously confirmed that a nickel-plated surface provides advantages over a palladium-plated surface. ${ }^{26}$ $\mathrm{Hg} / \mathrm{HgO}$ was used as the reference electrode, $\mathrm{Pt}$ as the counter electrode. The cathodic cell (the charging side) was filled with $0.2 \mathrm{~mol} / \mathrm{L} \mathrm{H}_{2} \mathrm{SO}_{4}$ and the anodic cell (the oxidizing side) was filled with a $0.2 \mathrm{~mol} / \mathrm{L} \mathrm{NaOH}$ solution. The potential for passivation was $0.2 \mathrm{~V}$ (vs $\mathrm{Hg} / \mathrm{HgO}$ ) and the cathodic charging-current density was $-5 \mathrm{~mA} / \mathrm{cm}^{2}$. Until the passive-current density was less than $0.1 \mu \mathrm{A} / \mathrm{cm}^{2}$, a corrosion solution $(3.5 \% \mathrm{NaCl}+\mathrm{x}$ $\mathrm{mol} / \mathrm{L} \mathrm{Na}_{2} \mathrm{MoO}_{4} \mathrm{x}=0,0.005,0.05,0.2$ ) was added to the charging side, and the charging current of $-5 \mathrm{~mA} / \mathrm{cm}^{2}$ was used simultaneously. The experimental set-up was shown in the previous paper. ${ }^{27}$

\subsection{Polarization-curve measurements}

Potentiodynamic-polarization measurement was carried out with Gamry reference 600. A value of $0.3 \mathrm{mV} / \mathrm{s}$ was chosen for the scan rate, sweeping from $-200 \mathrm{mV}$ (vs OCP) to the potential value, at which the sudden current density was about $0.1 \mathrm{~mA} / \mathrm{cm}^{2}$. The pitting potential was identified as the value, at which the current density exceeded $0.1 \mathrm{~mA} / \mathrm{cm}^{2}$. To avoid crevice corrosion, all the specimens were pre-passivated in $65 \%$ $\mathrm{HNO}_{3}$ at $70{ }^{\circ} \mathrm{C}$ for $1 \mathrm{~h}$, rinsed with water and methanol, dried with cool air and then mounted in self-cure acrylic.

\subsection{EIS test}

Electrochemical experiments were carried out in a three-electrode cell with platinum as the counter electrode (CE) and a saturated calomel electrode (SCE) coupled with a fine Luggin capillary as the reference electrode. The test surface area of a specimen was $1.0 \mathrm{~cm} \times 1.0 \mathrm{~cm}$, and all the samples were ground with 1200 -grit $\mathrm{SiC}$ paper and then degreased ultrasonically in acetone for 5 min prior to washing with distilled water. The open-circuit potential (OCP) was measured for 1 hour at $20{ }^{\circ} \mathrm{C}$ before the measurements to stabilize the rest potential.

EIS tests were conducted under the open-circuit condition. Measurements were performed between $10 \mathrm{mHz}$ to $10^{5} \mathrm{~Hz}$, at the 10 date decade and $5 \mathrm{mV}$ ac amplitude. The impedance data were analyzed with the Zview 2.70 software package and fitted to the appropriate equivalent 


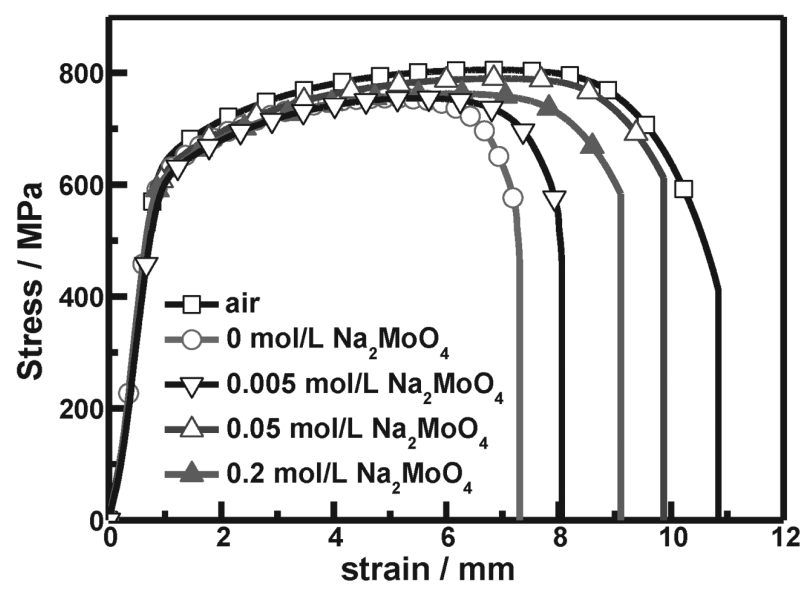

Figure 2: Stress-strain curves for DSS in different solutions

circuit. All the tests were performed in $0.2 \mathrm{~mol} / \mathrm{L} \mathrm{H}_{2} \mathrm{SO}_{4}$ $+3.5 \% \mathrm{NaCl}+x \mathrm{~mol} / \mathrm{L} \mathrm{Na}_{2} \mathrm{MoO}_{4}(x=0,0.005,0.05$, $0.2)$ at $20{ }^{\circ} \mathrm{C}$.

\subsection{Microstructure examination}

For the microstructure examination of the alloy, the as-received alloy was ultrasonically cleaned, then washed with alcohol, dried and electro-etched in a $4 \mathrm{~mol} / \mathrm{L} \mathrm{NaOH}$ solution at $20^{\circ} \mathrm{C}$, at a $2 \mathrm{~V} \mathrm{DC}$ potential applied for about $30 \mathrm{~s}$. A microscopic examination of the pitting morphology was performed on the samples after the anodic polarization beyond the pitting potential. In order to assess whether a molybdate-oxidized film was formed, Renishaw Raman spectroscopy was used near the pits using a $514 \mathrm{~nm} \mathrm{Ar}^{+}$laser.

\section{RESULTS}

\subsection{SSRT}

Figure 2 shows the strain-stress curves of the 2205 DSS in different solutions at $20{ }^{\circ} \mathrm{C}$. As shown in this figure, in a $0.2 \mathrm{~mol} / \mathrm{L} \mathrm{H}_{2} \mathrm{SO}_{4}+3.5 \% \mathrm{NaCl}$ solution, the elongation was reduced by about $4 \mathrm{~mm}$ more than in air. The elongation increased after $0.005 \mathrm{~mol} / \mathrm{L} \mathrm{Na} \mathrm{MoO}_{4}$ was added. The elongation increased to the level obtained in air while $0.05 \mathrm{~mol} / \mathrm{L} \mathrm{Na}_{2} \mathrm{MoO}_{4}$ was added. After the concentration increased to $0.2 \mathrm{~mol} / \mathrm{L}$, the elongation decreased slightly. In order to investigate the SCC susceptibility, the reduction in the area loss factor $\left(F_{\mathrm{R}}\right)$ was calculated as follows: ${ }^{28}$

$$
F_{\mathrm{R}}=\left[1-\frac{R_{\mathrm{E}}}{R_{0}}\right] \times 100 \%
$$

where $R_{\mathrm{E}}$ is the reduction in area in the sulfuric acid solution, and $R_{0}$ is the reduction in area in air. The calculated values for $0.2 \mathrm{~mol} / \mathrm{L} \mathrm{H}_{2} \mathrm{SO}_{4}+\mathrm{n} 3.5 \% \mathrm{NaCl}+$ $x \mathrm{~mol} / \mathrm{L} \mathrm{Na}_{2} \mathrm{MoO}_{4}(x=0,0.005,0.05,0.2)$ are 19.4, $15.6,3.8$ and $7.5 \%$, respectively. $\mathrm{F}_{\mathrm{R}}$ in $0.05 \mathrm{~mol} / \mathrm{L}$ $\mathrm{Na}_{2} \mathrm{MoO}_{4}$ is lower than in $0 \mathrm{~mol} / \mathrm{L} \quad \mathrm{Na}_{2} \mathrm{MoO}_{4}$, suggesting that the SCC susceptibility increases in
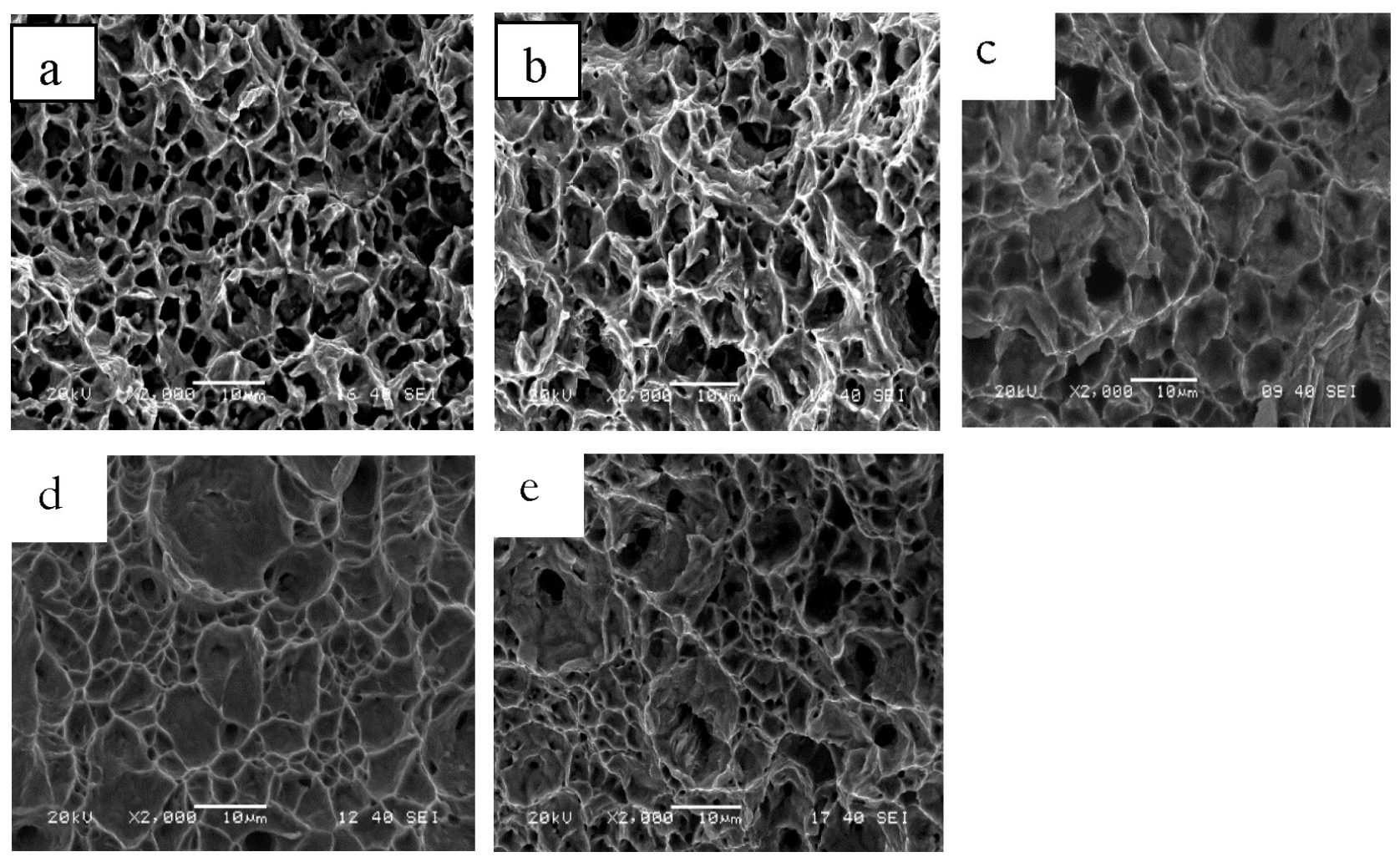

Figure 3: Fracture morphology of 2205 DSS in different solutions: a) in air, b) 0 mol/ $/ \mathrm{Na}_{2} \mathrm{MoO}_{4}$, c) $\left.0.005 \mathrm{~mol} / \mathrm{L} \mathrm{Na} 2 \mathrm{MoO}_{4}, \mathrm{~d}\right) 0.05 \mathrm{~mol} / \mathrm{L}$ $\mathrm{Na}_{2} \mathrm{MoO}_{4}$, e) $0.2 \mathrm{~mol} / \mathrm{L} \mathrm{Na} \mathrm{MoO}_{4}$ 


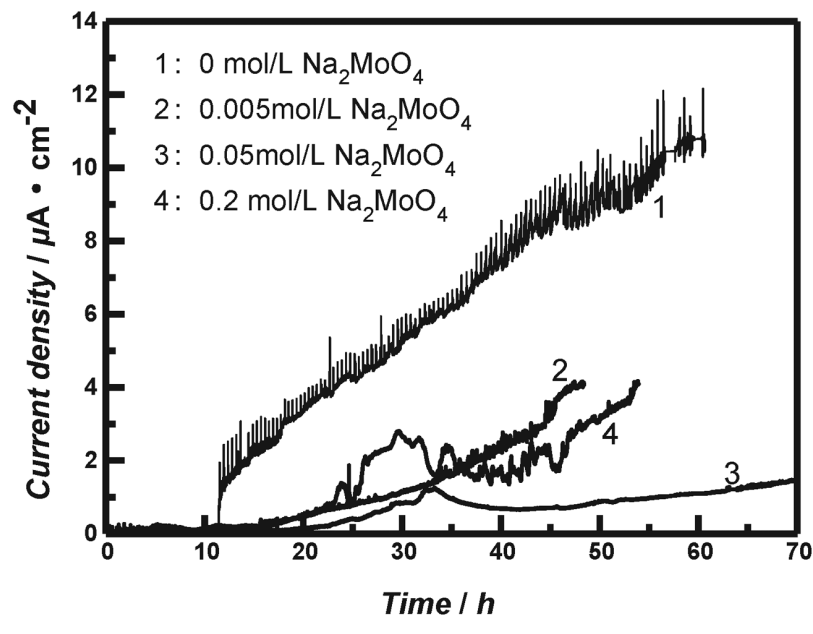

Figure 4: Hydrogen-permeation curves for 2205 DSS in different solutions

$0 \mathrm{~mol} / \mathrm{L} \mathrm{Na}_{2} \mathrm{MoO}_{4}$. When $0.05 \mathrm{~mol} / \mathrm{L} \mathrm{Na}_{2} \mathrm{MoO}_{4}$ was added into the test solution, the SCC susceptibility decreased.

Figure 3 shows the fracture morphology of the 2205 DSS in different solutions. Brittle fracture was found in $0 \mathrm{~mol} / \mathrm{L} \mathrm{Na}_{2} \mathrm{MoO}_{4}$, and it disappeared when $\mathrm{Na}_{2} \mathrm{MoO}_{4}$ was added. This was consistent with the SSRT results.

In order to explain the SSRT results, new experiments were carried out including hydrogen permeation and pitting corrosion.

\subsection{Hydrogen-permeation test}

Figure 4 shows the hydrogen-permeation curves of the 2205 DSS in different solutions. In $0 \mathrm{~mol} / \mathrm{L}$ $\mathrm{Na}_{2} \mathrm{MoO}_{4}$, the current density increased gradually with the increasing time. The hydrogen-permeation current decreased when $\mathrm{Na}_{2} \mathrm{MoO}_{4}$ was added. The hydrogenpermeation current showed the minimum value when the concentration of $\mathrm{Na}_{2} \mathrm{MoO}_{4}$ was $0.05 \mathrm{~mol} / \mathrm{L}$. When the concentration of $\mathrm{Na}_{2} \mathrm{MoO}_{4}$ increased to $0.2 \mathrm{~mol} / \mathrm{L}$, the hydrogen-permeation current showed no obvious change compared with $0.005 \mathrm{~mol} / \mathrm{L}$. Molybdate had an inhibiting effect on the hydrogen permeation across the 2205 DSS. Hydrogen diffusivity $(D)$ was calculated with the time-lag method: $D=L^{2} / 6 t_{\mathrm{L}}$ where $D$ is the hydrogen diffusivity, $\mathrm{L}$ is the specimen thickness, and the time of $t_{\mathrm{L}}$ corresponds to the point on the hydrogen permeation curve, at which it is $0.63 \mathrm{i}^{8}$. The steady-state hydrogenpermeation current values for $0.2 \mathrm{~mol} / \mathrm{L} \mathrm{H}_{2} \mathrm{SO}_{4}+3.5 \%$ $\mathrm{NaCl}+x \mathrm{~mol} / \mathrm{L} \mathrm{Na}_{2} \mathrm{MoO}_{4}(x=0,0.005,0.05,0.2)$ are $10.6 \mu \mathrm{A} / \mathrm{cm}^{2}, 3.2 \mu \mathrm{A} / \mathrm{cm}^{2}, 1.1 \mu \mathrm{A} / \mathrm{cm}^{2}$ and $2.9 \mu \mathrm{A} / \mathrm{cm}^{2}$, respectively. The $D$ values are $108 \times 10^{-16} \mathrm{~cm}^{2} / \mathrm{s}$, $5.69 \times 10^{-16} \mathrm{~cm}^{2} / \mathrm{s}, 2.58 \times 10^{-16} \mathrm{~cm}^{2} / \mathrm{s}$ and $4.26 \times 10^{-16} \mathrm{~cm}^{2} / \mathrm{s}$, respectively.

\subsection{Potentiodynamic-polarization measurement}

The potentiodynamic-polarization curves are shown in Figure 5. With an increased molybdate concentration, the anodic process was inhibited and the corrosion potential showed no obvious change. This indicated that the anodic passivation film became compact. Moreover, the pitting potential increased with the molybdate-concentration increase to $0.05 \mathrm{~mol} / \mathrm{L}$ and slightly decreased when the molybdate concentration was up to $0.2 \mathrm{~mol} / \mathrm{L}$.

\subsection{EIS test}

Impedance spectra measured at the open-circuit potential were recorded after $30 \mathrm{~min}$ of immersion. This time is sufficiently long to stabilize the open circuit potential (OCP), and a stable passivation film can be formed after a 30-min immersion. ${ }^{1,29}$ Nyquist plots for different solutions are shown in Figure 6.

The capacitive responses were fitted with constant phase elements, CPEs, whose impedance was defined as shown in Equation (2):

$$
Z_{\mathrm{CPE}}=\frac{1}{Y_{0}(j 2 \pi f)^{n}}
$$

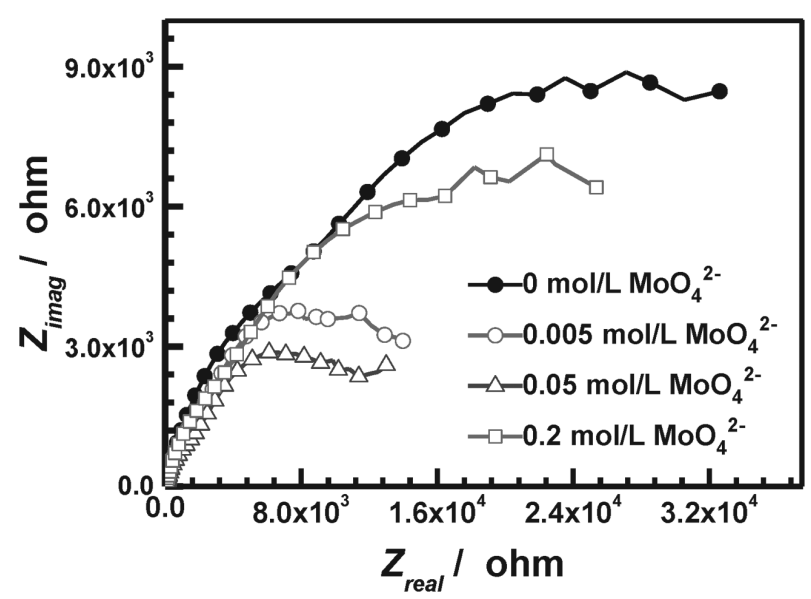

Figure 6: Nyquist curves for DSS 2205 with different concentrations of molybdate
Figure 5: Potentiodynamic-polarization curves for different molybdate concentrations 


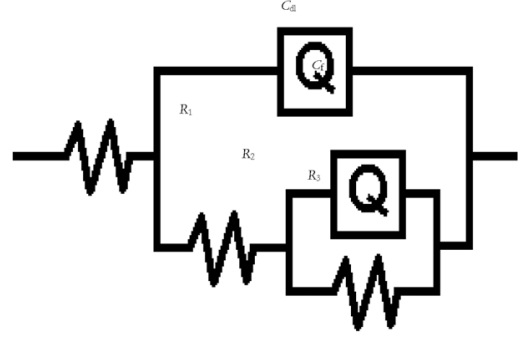

Figure 7: Equivalent circuit of duplex stainless steel in the solution

where $Y_{0}$ is the CPE, $j=\sqrt{-1}, f$ is the frequency $(\mathrm{Hz})$, the exponent $n$ is equal to $\alpha /(\pi / 2)$, and $\alpha$ is the phase angle of the CPE (radians).

The equivalent circuit of DSS in each solution is shown in Figure 7; $R_{1}, R_{2}$, and $R_{3}$ are the resistance of the solution, charge transfer resistance, and film resistance, respectively, while $C_{\mathrm{dl}}$ and $C_{\mathrm{f}}$ represent the respective $C P E$ of the double layer and $C P E$ of the oxide film. The values of the parameters are given in Table 1.

Table 1: Values of equivalent circuit parameters

\begin{tabular}{|c|c|c|c|c|c|}
\hline $\begin{array}{c}\mathrm{MoO}_{4}{ }^{2-} \\
\text { concentration }\end{array}$ & $R_{1}(\Omega)$ & $\begin{array}{c}R_{2}(\Omega \\
\left.\mathrm{cm}^{2}\right)\end{array}$ & $\begin{array}{c}C_{\mathrm{dl}}(\mathrm{F} \\
\left.\mathrm{cm}^{-2}\right)\end{array}$ & $\begin{array}{c}R_{3}(\Omega \\
\left.\mathrm{cm}^{2}\right)\end{array}$ & $\begin{array}{c}C_{\mathrm{f}}(\mathrm{F} \\
\left.\mathrm{cm}^{-2}\right)\end{array}$ \\
\hline $0 \mathrm{~mol} / \mathrm{L}$ & 0.85 & 7882 & $1.056 \mathrm{E}-5$ & $2.606 \mathrm{E} 4$ & $5.574 \mathrm{E}-5$ \\
\hline $0.005 \mathrm{~mol} / \mathrm{L}$ & 0.92 & 3274 & $2.522 \mathrm{E}-5$ & 8900 & $8.258 \mathrm{E}-5$ \\
\hline $0.05 \mathrm{~mol} / \mathrm{L}$ & 0.96 & 2729 & $2.867 \mathrm{E}-5$ & 8149 & $8.775 \mathrm{E}-5$ \\
\hline $0.2 \mathrm{~mol} / \mathrm{L}$ & 1.32 & 6203 & $1.874 \mathrm{E}-5$ & $1.113 \mathrm{E} 4$ & $8.043 \mathrm{E}-5$ \\
\hline
\end{tabular}

Two time constants were used for EIS. The time constant at low frequencies indicates the formation of an oxide film, while high-frequency constant is associated with the charge transfer resistance. ${ }^{20-23} R_{3}$ and $C_{\mathrm{f}}$ represent the resistance of the oxide film and the adsorption of the inhibitor, respectively. The charge transfer during the electrochemical reaction is attributed to $C_{\mathrm{dl}}$ and $R_{2}$, which correspond to the respective capacitance of the passive layer (including the defects) and the charge transfer resistance.

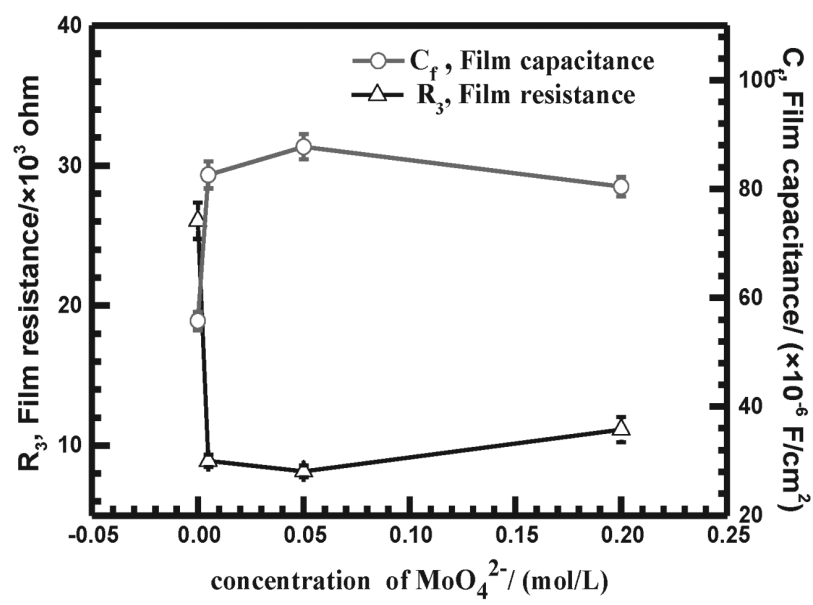

Figure 8: $R_{3}$ and $C_{\mathrm{f}}$ (from Figure 6) curves of DSS 2205 with different concentrations of molybdate

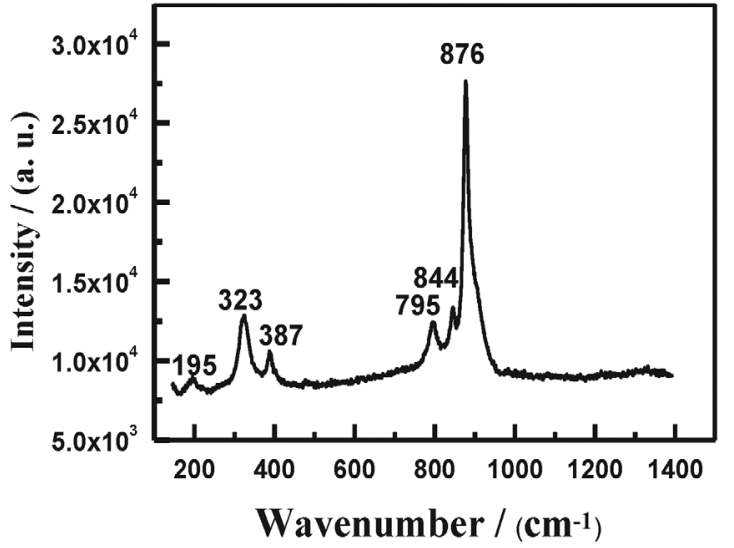

Figure 9: Raman spectrum for different sites of the pits

Changes in the film capacitance $\left(C_{\mathrm{f}}\right)$ can be used as indicators of the changes in the film thickness. Figure 8 shows that the value of $C_{\mathrm{f}}$ increases initially and then decreases slightly with the increasing concentration of molybdate; in other words, a barrier layer that depends on the concentration of molybdate, forms on the surfaces of the samples in the solution and the thickness of the film increases initially and then remains constant.

\subsection{Pit observation}

Figure 9 shows the Raman spectrum for the surface.

Figure 10 shows the morphology of the pits after potentiostatic polarization in $0 \mathrm{~mol} / \mathrm{L} \mathrm{Na}_{2} \mathrm{MoO}_{4}$ and 0.05 $\mathrm{mol} / \mathrm{L} \mathrm{Na}_{2} \mathrm{MoO}_{4}$.

$\mathrm{MoO}_{2}$ exhibits Raman shifts of $(203,228,345,363$, $461,495,571,589$, and 744) $\mathrm{cm}^{-1},{ }^{26} \mathrm{MoO}_{3}$ exhibits shifts of $\left(160,219,338,366,381,473,822\right.$, and 998) $\mathrm{cm}^{-1} .^{27}$ The pits (Figure 9) formed in this work resulted in shifts of $(323,387,479,796$, and 876$) \mathrm{cm}^{-1}$, which differ from those of molybdenum oxides. This indicates that no oxidation formed on the metal surface.
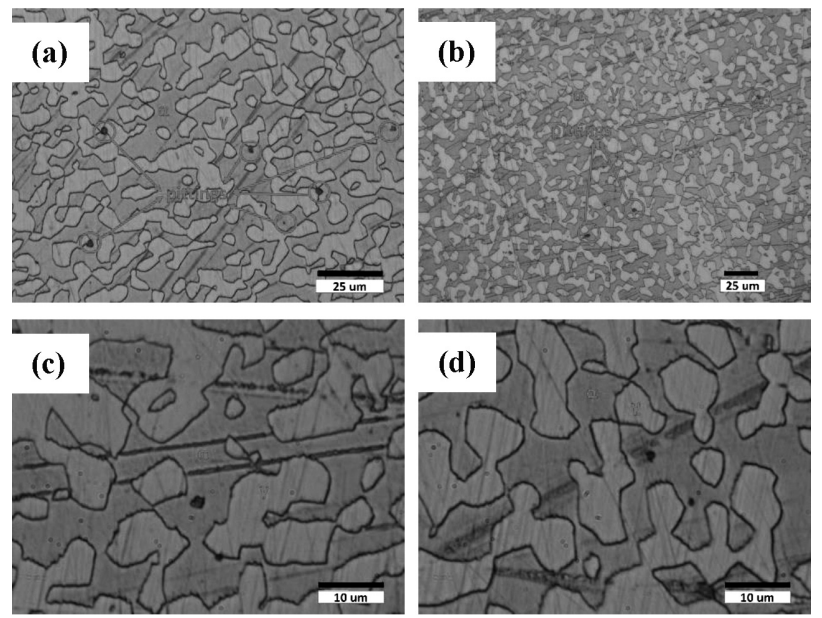

Figure 10: Pitting morphology (ferrite is dark, austenite is light) of the samples after polarization: a), c): $0 \mathrm{~mol} / \mathrm{L} \mathrm{Na}_{2} \mathrm{MoO}_{4}$; b), d) 0.05 $\mathrm{mol} / \mathrm{L} \mathrm{Na}_{2} \mathrm{MoO}_{4}$ 
In Figure 10, fewer and smaller pits are observed in the solution containing $0.05 \mathrm{~mol} / \mathrm{L}$ molybdate than in the solution without molybdate. These pits were mainly observed in the ferrite and austenite boundary region, propagating in the ferrite phase..$^{28}$

In summary, the results confirm a beneficial influence of the molybdate inhibitor on the pitting-corrosion resistance of the 2205 DSS.

\section{DISCUSSION}

Reactions (1), (2) and (3) occurred and reduction products are believed to be deposited on the metal surface. ${ }^{5,30,31}$ These products inhibit the $\mathrm{Cl}^{-}$attack of the passive film and thereby delay pitting corrosion.

$$
\begin{gathered}
\mathrm{MoO}_{4}{ }^{2-}+4 \mathrm{H}^{+}+2 \mathrm{e}^{-} \rightarrow \mathrm{MoO}_{2}+2 \mathrm{H}_{2} \mathrm{O} \\
7 \mathrm{MoO}_{4}{ }^{2-}+8 \mathrm{H}^{+} \leftrightarrows \mathrm{Mo}_{7} \mathrm{O}_{24}{ }^{6-}+4 \mathrm{H}_{2} \mathrm{O} \\
\mathrm{Mo}_{7} \mathrm{O}_{24}{ }^{6-}+3 \mathrm{H}^{+}+\mathrm{HMoO}_{4} \stackrel{\leftrightarrows}{\leftrightarrows} \mathrm{Mo}_{8} \mathrm{O}_{24}{ }^{4-}
\end{gathered}
$$

Various adsorption isotherms, e.g., Frumkin, Langmuir, Frieundlich and Temkin isotherms were attempted to establish the appropriate one. The best fit was obtained with the Langmuir adsorption isotherm. Equation (4) is based on the Langmuir adsorption-isotherm equation where $C, K_{\text {ads }}$, and $\theta$ are the cocentration of molybdate, adsorption-equilibrium constant and surface coverage, respectively:

$$
C / \theta=\left(1 / K_{\mathrm{ads}}\right)+C
$$

On the other hand, $\theta$ was calculated with the following relation: ${ }^{32}$

$$
\theta=\left(W_{0}-W\right) /\left(W_{0}-W_{\mathrm{m}}\right)
$$

where $W$ and $W_{0}$ are the weight loss of stainless steel with and without an addition of the inhibitor in the solution, respectively, and $W_{\mathrm{m}}$ is the smallest weight loss.

Figure 11 shows the plot of $C / \theta$ vs $C$, yielding a straight line with a slope very close to 1 and regression coefficient $\left(R^{2}\right)$ being near 1 . This suggests that the

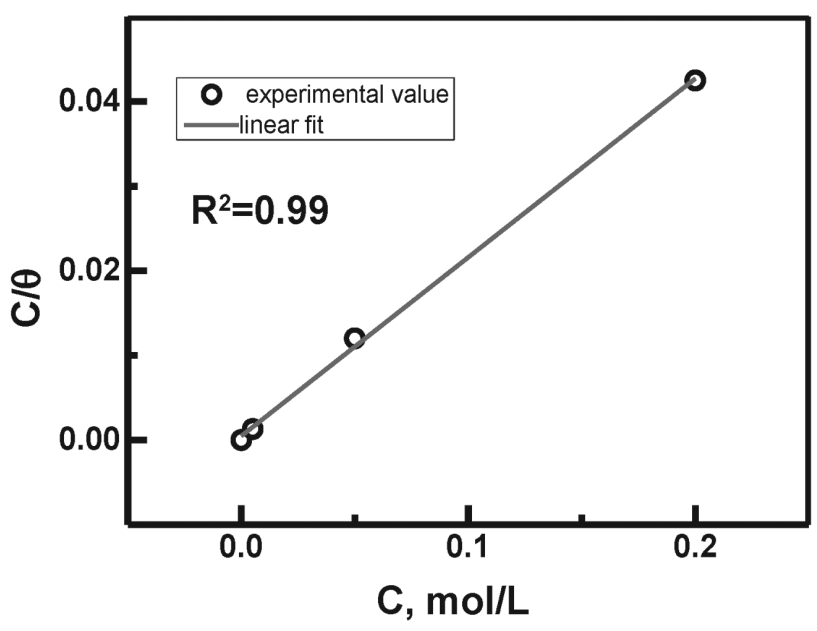

Figure 11: Langmuir adsorption isotherm adsorption of molybdate obeys the Langmuir adsorption isotherm. The adsorption accounts for one monolayer or less. This indicates that the addition of molybdate forms an adsorption film on the metal surface and the film consists of one monolayer or less. When the adsorption is completed, the film becomes steady.

Moreover, the film-induced stress restarts the nucleation and propagation of the cracks during SCC. A tensile stress is applied to the sample during SSRT. The applied stress, $\sigma_{\text {appl }}$, and the film-induced stress, $\sigma_{\mathrm{p}}$, together result in the nucleation and propagation of cracks. The driving force for the crack nucleation and propagation is expressed with the following Equations (3-5):

$$
\begin{gathered}
\sigma_{\text {tip }}=\sigma_{\text {appl }}+\sigma_{\mathrm{p}} \\
\frac{\mathrm{d} \sigma_{\text {tip }}}{\mathrm{d} t}=\frac{\mathrm{d} \sigma_{\text {appl }}}{\mathrm{d} t}+\frac{\mathrm{d} \sigma_{\mathrm{p}}}{\mathrm{d} t} \\
I s c c=\alpha \frac{\mathrm{d} \sigma_{\text {tip }}}{\mathrm{d} t}=\alpha\left(\frac{\mathrm{d} \sigma_{\text {appl }}}{\mathrm{d} t}+\frac{\mathrm{d} \sigma_{\mathrm{p}}}{\mathrm{d} t}\right)=\beta+\alpha \frac{\mathrm{d} \sigma_{\mathrm{p}}}{\mathrm{d} t}
\end{gathered}
$$

The value of $\sigma_{\mathrm{p}}$ remains constant with the immersion time in the solution because the adsorption of molybdate accounts for one monolayer or less. When $\sigma_{\text {tip }}$ increases to the critical level, a crack nucleates. The increased rate of the crack tip stress can be obtained with Equation (3). Under slow-rate tensile conditions with the same strain rate, it is reasonable to assume that $\mathrm{d} \sigma_{\text {appl }} / d t$ is a constant. By assuming the susceptibility to SCC to be $I_{\mathrm{SCC}} \propto$ $\mathrm{d} \sigma_{\text {tip }} / \mathrm{d} t$, Equation (5) was obtained. Equation (5) shows that the susceptibility to SCC, $I_{\mathrm{SCC}}$, is a constant value since $\mathrm{d} \sigma_{\mathrm{p}} / \mathrm{d} t$ is constant. This indicates that $I_{\mathrm{SCC}}$ has no relation with the adsorption film on the surface.

As Figure 4 shows, molybdate inhibits hydrogen permeation. During the hydrogen-permeation process, hydrogen atoms are adsorbed on the metal surface and then they permeate into the steel due to diffusion. The diffusion speed depends on the microstructure, hydrogen-atom concentration on the metal surface and temperature. ${ }^{19}$ Moreover, the permeation is driven by the concentration gradient of hydrogen; in other words, hydrogen diffuses from the high-concentration region to the low-concentration region. ${ }^{27}$ The adsorption area decreases after the additions of molybdate, due to the adsorption of molybdate onto the metal surface. Moreover, hydrogen atoms are consumed through reactions (1), (2) and (3). Hydrogen atoms adsorbed on the metal surface decrease. This decrease leads to a reduction in the driving force for permeation, hence decreasing the diffusion rate of hydrogen atoms in the molybdate solution.

The inhibiting effect of molybdate has been extensively studied. 5,7,30,31 Molybdate is said to inhibit the initiation of SCC by blocking the propagation of an intergranular attack. As shown in Figure 5, the pitting potentials increase with an increasing concentration of molybdate. This concurs with previously reported results regarding the inhibition effect of molybdate on the 
resistance of the 2205 DSS to pitting corrosion. ${ }^{7}$ In Figure 10, fewer and smaller pits are observed in the solution containing $0.05 \mathrm{~mol} / \mathrm{L}$ molybdate than in the solution without molybdate. These pits are mainly observed in the ferrite and austenite boundary region, propagating in the ferrite phase. Molybdate forms a salt layer on the surface of DSS that blocks the adsorption of $\mathrm{Cl}^{-}$. The competitive-adsorption-mechanism model involving $\mathrm{Cl}$ - and molybdate was given in a previous paper. $^{27}$

Electrochemical-impedance curves of the 2205 DSS were obtained in order to elucidate the influence of the molybdate effect. The curves for different solutions (Figure 6) are compared. As shown in Figure 8, $\mathrm{C}_{\mathrm{f}}$ increases initially and then decreases with the increasing concentration of molybdate. The effect of molybdate is similar to that of the corrosion inhibitor. At low concentrations of molybdate, the local concentration of $\mathrm{Cl}^{-}$ increases, thereby resulting in an accelerated dissolution of the matrix and, hence, increased values of $\mathrm{C}_{\mathrm{f}}$. However, molybdate is adsorbed on the metal surface at high concentrations; hence $\mathrm{Cl}^{-}$becomes separated from the surface of $\operatorname{DSS}^{29,30}$, thereby resulting in decreasing values of $\mathrm{C}_{\mathrm{f}}$. The value of $R_{3}$ increases (Figure 8) owing possibly to a decrease in the corrosion rate and also to the adsorption of the inhibitor. Furthermore, $R_{3}$ decreases owing possibly to the partial adsorption of the inhibitor, which in turn leads to an increase in the local concentration of $\mathrm{Cl}^{-}$and accelerated dissolution of the matrix.

\section{CONCLUSIONS}

1. Molybdate reduces the SCC susceptibility of the 2205 DSS in $\mathrm{H}_{2} \mathrm{SO}_{4}$ by improving the pitting-corrosion resistance and decreasing the hydrogen permeation into the steel.

2. Molybdate is adsorbed on the metal surface. The adsorption obeys the Langmuir adsorption-isotherm equation and accounts for one monolayer or less. Based on the Raman experiment, no oxidized molybdate was formed on metal surface.

3. Molybdate hinders the hydrogen-permeation current by decreasing the active metal surface and hydrogen-atom adsorption.

\section{Acknowledgement}

This work was financially supported by the Natural Science Foundation of the Jiangsu Province, China, (No. BK20141292).

\section{REFERENCES}

${ }^{1}$ S. A. M. Refaey, Inhibition of steel pitting corrosion in $\mathrm{HCl}$ by some inorganic anions, Appl. Surf. Sci., 240 (2005), 396-404, doi:10.1016/j.apsusc.2004.07.014

${ }^{2}$ C. B. Zheng, B. H. Yan, Electrochemical investigation on the hydrogen permeation behavior of 7075-T6 Al alloy and its influence on stress corrosion cracking, Inter. J. of Miner. Metall. \& Mater., 35 (2017), 729-737, doi:10.1007/s12613-015-1128-5

${ }^{3}$ W. J. Tobler, S. Virtanen, Effect of Mo species on metastable pitting of Fe18Cr alloys - a current transient analysis, Corros. Sci., 48 (2006), 1585-1607, doi:10.1016/j.corsci.2005.05.049

${ }^{4}$ C. R. Alentejano, I. V. Aoki, Localized corrosion inhibition of 304 stainless steel in pure water by oxyanions tungstate and molybdate, Electrochim. Acta, 49 (2004), 2779-2785, doi:10.1016/j.electacta. 2004.01.039

${ }^{5}$ F. Eghbali, M. H. Moayed, Critical pitting temperature (CPT) assessment of 2205 duplex stainless steel in $0.1 \mathrm{M} \mathrm{NaCl}$ at various molybdate concentrations, Corros. Sci., 53 (2011), 513-522, doi:10.1016/j.corsci.2010.08.008

${ }^{6} \mathrm{C}$. B. Zheng, G. Yi, Investigating the influence of hydrogen on stress corrosion cracking of 2205 duplex stainless steel in sulfuric acid by electrochemical impedance spectroscopy, Corros. Rev., 35 (2017), 23-33, doi:10.1515/corrrev-2016-0060

${ }^{7}$ M. Saremi, C. Dehghanian, M. Mohammadi Sabet, The effect of molybdate concentration and hydrodynamic effect on mild steel corrosion inhibition in simulated cooling water, Corros. Sci., 48 (2006), 1404-1412, doi:10.1016/j.corsci.2005.06.009

${ }^{8}$ M. Jafarian, F. Gobal, I. Danaee, R. Biabani, M. G. Mahjani, Electrochemical studies of the pitting corrosion of tin in citric acid solution containing Cl-, Electrochim. Acta, 53 (2008), 4528-4536, doi:10.1016/j.electacta.2008.01.051

${ }^{9}$ C. B. Zheng, H. Y. Qu, W. Wang, EIS and SKP study on improvement of the protection performance of an alkyd-varnish coating modified with air-plasma treatment on Q235 Steel, Mater. Tehnol., 51 (2017), 911-918, doi:10.17222/mit.2017.022

${ }^{10}$ X. G. Feng, Y. Zuo, Y. M. Tang, X. H. Zhao, J. M. Zhao, The influence of strain on the passive behavior of carbon steel in cement extract, Corros. Sci., 65 (2012), 542-548, doi:org /10.1016/j. corsci. 2012.08.060

${ }^{11}$ C. B. Zheng, C. Wang, Effect of Stress on Hydrogen Permeation for X70 Carbon Steel in Seawater, Mater. Perform., 56 (2017), 54-58

${ }^{12}$ H. Luo, C. F. Dong, X. G. Li, K. Xiao, The electrochemical behavior of 2205 duplex stainless steel in alkaline solutions with different $\mathrm{pH}$ in the presence of chloride, Electrochim. Acta, 64 (2012), 211-220, doi:10.1016/j.electacta.2012.01.025

${ }^{13}$ T. Zakroczymski, E. Owczarek, Electrochemical investigation of hydrogen absorption in a duplex stainless steel, Acta Mater., 50 (2002), 2701-2713, doi:10.1016/S1359-6454(02)00105-2

${ }^{14}$ Hua Tan, Yiming Jiang, Bo Deng, Tao Sun, Juliang Xu, Jin Li, Effect of annealing temperature on the pitting corrosion resistance of super duplex stainless steel UNS S32750, Mater. Charact., 60 (2009), 1049-1054, doi:10.1016/j.matchar.2009.04.009

${ }^{15}$ L. Q. Guo, M. Li, X. Li. Shi, Y Yan, X.Y. Li, L.J. Qiao, Effect of annealing temperature on the corrosion behavior of duplex stainless steel studied by in situ techniques, Corro. Sci., 53 (2011), 3733-3741, doi:10.1016/j.corsci.2011.07.019

${ }^{16}$ A. Igual Munoz, J. Garcia Anton, J. L. Guinon, V. Perez Herran, The effect of chromate in the corrosion behaviour of duplex stainless steel in LiBr solutions, Corros. Sci., 48 (2006), 4127-4151, doi:10.1016/j.corsci.2006.03.009

${ }^{17}$ M. Javidi, S. Bahalaou Horeh, Investigating the mechanism of stress corrosion cracking in near-neutral and high $\mathrm{pH}$ environment for API 5L X52 steel, Corros. Sci., 80 (2014), 213-220, doi:10.1016/j.corsci. 2013.11.031

${ }^{18}$ A. Shahriari, T. Shahrabi, A. A. Oskuie, A study on stress corrosion cracking of X70 pipeline steel in carbonate solution by EIS, J. Mater. Eng. Perform., 22 (2013), 1459-1470, doi:10.1007/s11665-0120418-6

${ }^{19}$ A. R. Alhoud, N. C. Renton, W. F. Deans, Hydrogen embrittlement of super duplex stainless steel in acid solution, Int. J. Hydrogen Energ., 35 (2010), 6455-6464, doi:10. 1016/j.ijhydene. 2010. 03.056 


\section{G. YI et al.: EFFECT OF MOLYBDATE ON THE STRESS CORROSION CRACKING OF $2205 \ldots$}

${ }^{20}$ P. Woollin, W. Murphy, Hydrogen embrittlement stress corrosion cracking of super duplex stainless steel, Corro., 35 (2001), 75-81, doi:10.71222/corro.2001.122

${ }^{21}$ S. S. M. Tavares, V. G. Silva, J. M. Pardal, J. S. Corte, Investigation of stress corrosion cracks in a UNS S32750 super duplex stainless steel, Eng. Fail. Analy., 35 (2013), 88-94, doi:10.1016 j. engfailanal.2012.12.013

${ }^{22}$ L. J. Qiao, J. M. Xiao, W. Y. Chu, et al., Concentration distribution of hydrogen at crack tip of austenitic stainless steel after stress corrosion and hydrogen charging, J. Chin. Soc. Corros. Prot, 9 (2009), 235-239

${ }^{23}$ C. B. Zheng, H. K. Jiang, Y. L. Huang, Hydrogen permeation behaviour of X56 steel in simulated atmospheric environment under loading, Corros. Eng. Sci. Technol., 46 (2011), 365-367, doi:10.1179/ 147842209X 12559428167689

${ }^{24}$ C. B. Zheng, X. Chen, ZrMoN films on 304 stainless steel as bipolar plates for PEMFCs using physical-vapor-deposition (PVD) technology, Mater. Tehnol., 51 (2017), 911-918, doi:10.17222/ mit.2016.316

${ }^{25}$ E. Fujioka, H. Nishihara, K. Aramaki, The inhibition of pit nucleation and growth on the passive surface of iron in a borate buffer solution containing Cl- by oxidizing inhibitors, Corros. Sci., 38 (1996), 1915-1933, doi:10.1016/S0010-938X(96)00075-3

${ }^{26}$ A. Pardo, M. C. Merino, A. E. Coy, F. Viejo, R. Arrabal, E. Matykina, Pitting corrosion behaviour of austenitic stainless steels combining effects of Mn and Mo additions, Corros. Sci., 50 (2008), 1796-1806, doi:10.1016/j.corsci.2008.04.005
${ }^{27}$ C. Zheng, L. Cai, Z. Tang, X. Shen, The Inhibition Effect of the Molybdate on Hydrogen Permeation of 2205 Duplex Stainless Steel, Surf. Coat. Techn., 287 (2016), 153-159, doi:10.1016/j.surfcoat. 2015.12.077

${ }^{28}$ H. Zhang, Y. L. Zhao, Z. D. Jiang, Effects of temperature on the corrosion behavior of $13 \mathrm{Cr}$ martensitic stainless steel during exposure to $\mathrm{CO}^{2}$ and $\mathrm{Cl}$ - environment, Mater. Lett., 59 (2005), 3370-3374, doi:10.1016/j.matlet.2005.06.002

${ }^{29}$ A. Igual Munoz, J. Garcia Anton, J. L. Guinon, V. Perez Herran, Inhibition effect of chromate on the passivation and pitting corrosion of a duplex stainless steel in $\mathrm{LiBr}$ solutions using electrochemical techniques, Corros. Sci., 49 (2007), 3200-3225, doi:10.1016/ j.corsci.2007.03.002

${ }^{30} \mathrm{G}$. O. Ilevbare, G. T. Burstein, The inhibition of pitting corrosion of stainless steels by chromate and molybdate ions, Corros. Sci., 45 (2003), 1545-1569, doi:10.1016/S0010-938X(02)00229-9

${ }^{31}$ C. B. Zheng, H. K. Jiang, Y. L. Huang, Hydrogen permeation behaviour of X56 steel in simulated atmospheric environment under loading, Corro. Eng. Sci. Techn., 46 (2011), 365-367, doi:10.1179/ 147842209X 12559428167689

${ }^{32}$ I. Sekine, Y. Hirakawa, Effect of 1-hydroxyethylidene-1, 1-diphosphonic acid on the corrosion of SS 41 steel in $0.3 \%$ sodium chloride solution, Corros., 42 (2012), 272-277, doi:10.1016/corros. 2012.06.035 